\title{
PENERAPAN MODEL PEMBELAJARAN KOOPERATIF TIPE MAKE A MATCH UNTUK MENINGKATKAN HASIL BELAJAR IPS SISWA
}

\author{
Guslinda Guslinda, Gustimal Witri \\ Pendidikan Guru Sekolah Dasar FKIP Universitas Riau \\ guslinda@lecturer.unri.ac.id , gustimal.witri@lecturer.unri.ac.id
}

\begin{abstract}
ABSTRAK
Penelitian ini dilatar belakangi dari rendahnya hasil belajar IPS siswa yaitu dari 20 siswa yang tuntas berjumlah 8 siswa (40\%) dan 12 siswa $(60 \%)$ tidak tuntas. Adapun rumusan permasalan yaitu, apakah penerapan model pembelajaran kooperatif tipe Make A Match dapat meningkatkan hasil belajar siswa kelas III SD Muhammadiyah 6 Pekanbaru. Tujuan penelitian ini adalah untuk meningkatkan hasil belajar IPS dengan penerapan model pembelajaran kooperatif tipe Make $A$ Match. Metode penelitian ini menggunakan Penelitian Tindakan Kelas (PTK), penelitian ini dilakukan dua siklus, setiap siklus dua pertemuan dan satu kali ulaganharian. Penelitian ini melibatkan siswa kelas III Muhammadiyah 6 Pekanbaru sebanyak 20 orang siswa. Tindakan ini dilakukan dari bulan Maret sampai bulan April 2017. Hasil belajar IPS diperoleh dari data awal dengan ratarata 59,75 berkategori kurang dengan ketuntasan minimal 70 dengan standar KKM. Pada siklus I UH I diperoleh rata-rata hasil belajar IPS 73,75 dengan kategori cukup, dan pada siklus II UH II hasil belajar meningkat kembali menjadi 80,50 berkategori baik. Hasil penelitian pada siklus pertama, guru pada saat proses pembelajaran kurang memahami metode kooperatif tipe Make A Match sehingga sulit menerapkannya. Tetapi pada siklus kedua, metode kooperatif Make A Match sudah dapat diterapkan secara maksimal. Ini ditandai dengan banyaknya siswa yang tuntas dalam pelajaran IPS ini. Simpulan dari penelitian ini adalah model kooperatif tipe Make $A$ Match telah berhasil diterapkan secara optimal dalam hasil belajar IPS dikelas III SD Muhammadiyah 6 Pekanbaru meningkat.
\end{abstract}

Kata Kunci :Model Pembelajaran Kooperatif, Tipe Make A Match, IPS

\section{ABSTRACT}

This study is based on the low learning students' social science outcomes. The purpose of this study is to improve the learning outcomes of IPS with the application of cooperative learning model type Make A Match. This research method using Action Research, this research conducted two cycles, each cycle of two meetings and one time test. This research conducted by 20 students of third grade elementary school. Result of this research obtained average students' learning outcomes 73.75 with enough categories and on the second cycle students' learning outcomes increased again to 80.50 categorized well. The results of the first cycle, the teacher during the learning process less understanding of the method of cooperative type Make A Match so difficult to apply. But in the second cycle, make A Match cooperative method can be applied maximally. The conclusion of this research was the model of make-Match type 
cooperative has been successfully applied optimally in the learning result social science class.

Keywords: Cooperative Learning Model, Type Make A Match, social science

\section{PENDAHULUAN}

Tujuan pembelajaran IImu Pengetahuan Sosial (IPS) di sekolah dasar adalah membentuk warga negara yang berkemampuan sosial dan yakin akan kehidupannya sendiri ditengah-tengah kekuatan fisik dan sosial, yang pada gilirannya akan menjadi warga negara yang baik dan bertanggung jawab.Menurut UU No.20 Tahun 2003 Sisdiknas, tujuan pendidkan IPS adalahuntuk mengembangkan pengetahuan, pemahaman, dan kemampuan analisis,peserta didik terhadap kondisi sosial masyarakat. Pola pembelajaran IPS menekankan pada unsur pendidikan dan pembekalan pada siswa.Penekanan pembelajaran bukan sebatas pada upaya menjelajahi siswa dengan sejumlah konsep yang bersifat hafalan belaka, melainkan diarahkan agar mereka memahami dan ikut serta dalam melakoni kehidupan masyarakat di lingkungannya, serta sebagai bekal bagi dirinya untuk melanjutkan pendidikan ke jenjang yang lebih tinggi.

Berdasarkan informasi dan wawancara dengan wali kelas III Muhammadiyah 6 pekanbaru diperoleh data hasil belajar IPS siswa, dari jumlah siswa 20 orang, jumlah siswa yang tuntas pembelajaran IPS 8 siswa (40\%) sedangkan siswa yang tidak tuntas adalah 12 siswa (60\%). Rendahnya hasil belajar siswa disebabkan oleh berbagai hal baik yang datang dari guru maupun dari siswa, diantaranya: 1) siswa banyak yang pasif dalam mengikuti pembelajaran karena metode yang digunakan guru tidak bervariasi, 2) siswa cendrung menghafal karena guru kurang menggaitkan materi pembelajaran dengan dunia nyata anak. 3) kurangnya komunikasi siswa dalam belajar IPS dan guru lebih berperan sebagai subjek pembelajaran,

Berdasarkan latar belakang yang telah diuraikan tersebut peneliti melakukan penelitian dengan judul " Penerapan Model Pembelajaran Kooperatif Tipe Make A Match untuk Meningkatkan Hasil belajar IPS siswa Kelas III SD Muhammadiyah 6 Pekanbaru.

Rumusan masalah dalam penelitian ini adalah apakah penerapan model pembelajaran kooperatif tipe make a match dapat meningkatkan hasil belajar IPS 
siswa kelas III SD Muhammadiyah 6 Pekanbaru. Tujuan penelitian ini adalah untuk meningkatkan hasil belajar IPS siswa kelas III SD Muhammadiyah 6 pekanbaru.Adapun manfaat dari penelitian ini adalah dapat meningkatkan kualitas dan hasil belajar siswa kelas III SD Muhammadiyah 6 Pekanbaru, bagi guru dapat menentukan dan penegelolaan pembelajaran.

Model pembelajaran kooperatif tipe make a match merupakan model pembelajaran kelompok yang merupakan suatu pendekatan mengajar yang dapat membantu siswa dalam mendalami materi pembelajaran. Menurut Joyce \& Weil dalam Huda, (2013), berpendapat bahwa "Model pembelajaran sebagai rencana atau pola yang dapat digunakan untuk membentuk kurikulum, mendesaian materimateri instruksional, dan memandu proses pengajaran di ruang kelas atau di setting yang berbeda."Model pembelajaran dapat dijadikan pola pilihan, artinya para guru boleh memilih model pembelajaran yang sesuai dan efisien untuk mencapai tujuan pendidikannya.lebih lanjut Miftahul Huda (2014) menjelaskan bahwa tujuan dari strategi ini adalah untuk mengali materi dan pemdalaman materi. Selanjutnya Rusman (2011) model make a match (membuat pasangan) merupakan salah satu jenis dari model dalam pembelajaran kooperatif.

Menurut Miftahul Huda (2014), sebelum penerapan model ini perlu beberapa persiapan yaitu: 1) Membuat beberapa pertanyaan yang sesuai dengan materi yang dipelajari (jumlahnya tergantung tujuan pembelajaran) kemudian menulisnya dalam kartu-kartu pertanyaan. 2) Membuat kunci kunci jawaban dari pertanyaanpertanyaan yang telah dibuat dan menulisnya dalam kartu-kartu jawaban. Akan lebih baik kartu pertanyaan dan kartu jawaban berbeda warna. 3) Membuat aturan yang berisi penghargaan bagi siswa yang berhasil dan sanksi bagi siswa yang gagal (disini guru dapat membuat aturan ini bersama-sama dengan siswa) 4) Menyediakan lembaran untuk mencatat pasangan-pasangan yang berhasil sekaligus untuk pengskoran presentasi.

Menurut Miftahul Huda (2014) sintak make a match adalah: 1) Guru menyampaikan materi pembelajaran. 2) Siswa dibagi ke dalam dua kelompok, misalnya kelompok A dan kelompok B. kedua kelompok berhadap-hadapan. 3) Guru membagikan kartu pertanyaan kepada kelopok A dan kartu jawaban kepada kelompok B. 5) Guru menyampaikan kepada siswa bahwa mereka harus mencari/ mencocokan kartu yang dipegang dengan kartu kelompok lain. Guru juga perlu 
menyampaikan batasan maksimum waktu yang ia berikan kepada mereka. 6) Guru memintak semua kelompok A untuk mencari pasangannya di kelompok B. jika mereka sudah menemukan pasangannya masing-masing, guru memintak mereka melaporkan diri kepadanya guru mencatat mereka pada kertas yang sudah disiapkan. 7) Jika waktu sudah habis mereka harus diberi tahukan bahwa waktu sudah habis. Siswa yang belum menemukan pasangannya dimintak untuk berkumpul tersendiri. 8) Guru memanggil satu pasang untuk presentasi. Pasangan lain dan siswa yang tidak mendapat pasangan memperhatikan dan memberi tanggapan apakah pasangan itu cocok atau tidak. 9) terakhir guru memberi konfirmasi tentang kebenaran dan kecocokan pertanyaan dan jawaban dari pasangan yang memberikan presentasi.10) Guru memanggil pasangan berikutnya, begitu seterusnya sampai seluruh pasangan melakukan presentasi.

Menurut Purwanto (2014) Hasil belajar adalah perubahan perilaku yang terjadi setelah mengikuti proses belajar mengajar sesuai dengan tujuan pendidikan. Karena manusia mempunyai potensi perilaku kejiawaan yang dapat didik dan diubah perilakunya yang meliputi domain kognitif, afektif, dan psikomotorik.Sedangkan menurut Agus Suprijono (2009) hasil belajar adalah perubahan perilaku secara keseluruhan bukan hanya salah satu aspek potensi kemanusian saja.Sedangkan yang dimaksud hasil belajar IPS adalah perubahan yang diperoleh siswa selama mengikuti proses pembelajaran IPS. Hasil belajar tersebut dapat berupa skor atau angka, pengetahuan siswa dalam pembelajaran IPS.

\section{METODE PENELITIAN}

Adapun tempat penelitian dilaksanakan dikelas III Muhammadiyah 6 Pekanbaru.Waktu pengambilan data dilakukan pada tanggal 10 Maret 2017 sampai dengan 30 April 2017. Subjek penelitian adalah siswa kelas III Muhammadiyah 6 Pekanbaruyang berjumlah 20siswa yang terdiri dari 4 siswa laki-laki dan 16 siswa perempuan. Bentuk penelitian ini adalah penelitian tindakan kelas. Peneliti dan guru bekerja sama dalam merencanakan tindakan kelas dan merefleksi hasil tindakan. Pelaksanaan tindakan dilakukan oleh peneliti dan guru kelas bertindak sebagai pengamat atau observer selama proses pembelajaran berlangsung. Sesuai dengan jenis penelitian tindakan kelas ini, maka desain 
penelitian tindakan kelas adalah model siklus dengan pelaksanaannya dengan dua siklus yaitu siklus I dan siklus II.Siklus I terdiri: perencanaan tindakan, pelaksanaan tindakan, pengamatan dan refleksi. Hasil pengamatan dan refleksi pada siklus I diadakan perbaikan proses pembelajaran pada siklus II. Instrumen dalam penelitian ini yaitu perangkat pembelajaran yang terdiri dari silabus, RPP, dan LKS. Kemudian instrumen pengumpulan data yang terdiri dari lembarobservasi dan tes hasil belajar siswa.

Analisis dalam penelitian ini menggunakan teknik analisis data, adapun data yang diperoleh meliputi:

\section{Analisis Guru dan Siswa}

Aktivitas guru dan siswa dianalisis melalui lembar pengamatan, aktivitas ini diperoleh dari pengamatan selama proses pembelajaran berlangsung yang sesuai dengan langkah-langkah model pembelajaran kooperatif tipe Make A Match.

$$
S=\frac{R}{N} \times 100 \%
$$

Aktivitas guru dan aktivitas siswa diamati oleh seorang observer. Peneliti menggunakan rumus KTSP dalam Syahrilfudin (2011) yaitu :

Keterangan :

$\mathrm{S}=$ Hasil yang di peroleh

$\mathrm{R}=$ Skor yang di capai guru / siswa

$\mathrm{N}=$ Skor maksimal

Tabel 1

Kategori Analisis Guru dan Siswa

\begin{tabular}{|c|c|}
\hline \% Interval & Kategori \\
\hline $90-100$ & Sangat Baik \\
$80-89$ & Baik \\
$65-79$ & Cukup \\
$55-64$ & Kurang \\
$\leq 54$ & Sangat Kurang \\
\hline
\end{tabular}

\section{Hasil Belajar Siswa}

Untuk menentukan hasil belajar siswa dapat dihitung dengan rumus yaitu Ketuntasan individu :

$$
\mathrm{S}=\frac{R}{N} X 100
$$

(Purwanto,2015) 
Keterangan:

$S$ : Nilai yang diharapakn/ dicari

$\mathrm{R}$ : Jumlah skor dari item atau soal yang dijawab benar

$\mathrm{N}$ : Skor maksimum dari tes tersebut

\section{Analisis Peningkatan Hasil Belajar}

Peningkatan hasil belajar yang telah didapat, dianalisis dengan menggunakan rumus persentase yaitu:

$$
\mathrm{P}=\frac{\text { Posrate-Baserate }}{\text { Baserate }} X 100 \% \quad \text { (Aqib dkk, 2011) }
$$

Keterangan:
$\mathrm{P}$
: Presentase peningkatan
Posrate : Nilai sesudah diberikan tindakan
Baserate : Nilai sebelum tindakan

\section{HASIL PENELITIAN}

\section{Tahap Persiapan Penelitian}

Pada tahap persiapan peneliti mempersiapkan segala sesuatu yang diperlukan yaitu berupa perangkat pembelajaran dan instrumen pengumpulan data.Perangkat pembelajaran terdiri dari bahan ajar berupa silabus, RPP, Lembar Kerja Siswa.Instrumen pengumpulan data yang digunakan adalah lembar pengamatan aktiviatas guru dan soal tes.

\section{Tahap Pelaksanaan Proses Pembelajaran}

Pada penelitian ini proses pembelajaran dengan menerapkan model pembelajaran kooperatif tipe Make $A$ Match, dilaksanakan dalam empat kali pertemuan. Siklus pertama dilaksanakan dua kali pertemuan.Berdasarkan data yang telah terkumpul kemudian dievaluasi guna menyempurnakan tindakan.Kemudian dilanjutkan dengan siklus kedua yang dilaksanakan dua kali pertemuan.

Tahap pembelajaran kegiatan dengan penerapan model pembelajaran kooperatif tipe Make $A$ Match ini adalah pada awal pembelajaran guru membuka pelajaran dengan mengucapkan salam, menyiapkan siswa dan mengabsen kehadiran siswa. Pada fase pertama (menyampaikan tujuan dan motivasi siswa) pada fase ini guru menumbuhkan semangat dan minat belajar siswa dengan cara mengajukan pertanyaan kepada siswa. Fase kedua (mendemonstrasikan pengetahuan atau bacaan). Pada fase ini guru menginformasikan garis-garis 
besar materi guna menuntut siswa dalam proses pembelajaran. Pada fase ketiga (mengorganisir peserta didik kedalam tim-tim belajar) siswa dibagi menjadi 5 kelompok dan masing-masing kelompok mendapat LKS. Fase keempat (membantu kerja tim dan belajar), guru menjelaskan kepada siswa tetang permainan Make A Match (Mencari pasangan), setiap siswa mendapat kartu soal dan kartu jawaban. Fase kelima (mengevaluasi) sebagai tindak lanjut, guru memberikan evaluasi. Evaluasi ini berupa soal-soal sebanyak lima butir soal yang berbentuk essay.Fase keenam (memberikan penghargaan) guru memberikan penghargaan kepada pasangan yang dapat menyelesaikan tugasnya dengan baik dan benar.

Data yang dikumpulkan dari penelitian ini adalah data tentang kemampuan belajar IPS siswa yaitu hasil ulangan harian siklus dan hasil observasi setiap kali pertemuan.

\section{Aktivitas guru}

Berdasarkan hasil pengamatan, aktivitas guru dalam penggunaan model pembelajaran kooperatif tipe Make $A$ Match pada kemampuan belajar IPS siswa mengalami peningkatan pada setiap pertemuan di siklus I, siklus II. Peningkatan aktivitas guru siklus I dan siklus II dapat dilihat pada tabel2, perbandingan siklus I dan siklus II berikut ini :

Tabel 2

Perbandingan Aktivitas Guru dalam penggunaan model pembelajaran koopratif tipe Make A Match siklus 1 dan siklus II

\begin{tabular}{|c|c|c|c|c|}
\hline Siklus & \multicolumn{2}{|c|}{ Siklus I } & \multicolumn{2}{c|}{ Siklus II } \\
\cline { 2 - 5 } Pertemuan ke- & P1 & P2 & P3 & P4 \\
\hline Jumlah skor & 18 & 19 & 21 & 23 \\
Skor maksimum & 24 & 24 & 24 & 24 \\
Persentase & $75 \%$ & $79,16 \%$ & $87,5 \%$ & $95,83 \%$ \\
Kategori & Cukup & Cukup & Baik & SangatBaik \\
\hline
\end{tabular}

Dengan melihat data dari tabel 2 dapat diketahui persentase dan skor aktivitas guru selama mengajar di dalamkelas dengan menerapkan model pembelajaran kooperatif tipe Make A Match. Pada siklus I, skor yang diperoleh aktivitas guru pada pertemuan pertama adalah 18 dengan persentase $75 \%$ hal ini tergolong dengan kategori cukup. Sedangkan pada pertemuan kedua siklus I 
aktivitas guru mengalami peningkatan, dimana persentae yang diperoleh adalah $79,16 \%$ dengan skor 19 dan masih menduduki pada kategori cukup. Hal ini terjadi dikarenakan guru masih canggung dalam proses pembelajaran di kelas, kemudian guru belum sepenuhnya menguasi langkah-langkah model pembelajaran kooperatif tipa Make A Match sehingga pada saat pemberian materi guru kurang memotivasi dan menyampaikan tujuan pembelajaran, dan pada saat proses pembelajaran guru juga masih sering lupa dalam tahapan membimbing siswa dalam mengerjakan tugas dan belajar siswa.

Observasi dilanjutkan pada siklus II, aktivitas guru pada pertemuan pertama siklus II mengalami peningkatan jumlah skor. Hal dapat dilihat dari jumlah persentae dan total skor yang didapatkan sebagaimana tercantum dalam table yaitu $87,5 \%$ atau 21 dengan kategori baik. Pada pertemuan II siklus II peningkatan aktivitas guru meningkat, adapun persentase yang diperoleh pada pertemuan II sikluasll ini sebesar $95,83 \%$ dengan jumlah skor 23 dan menduduki pada sangat baik.

\section{Aktivitas siswa}

Berdasarkan hasil pengamatan hasil belajar siswa dalam menggunakan model pembelajaran kooperatif tipe Make $A$ Match selama pembelajaran berlangsung selalu mengalami peningkatan pada setiap pertemuan siklus I dan siklus II. Peningkatan hasil belajar siklus I dan siklus II :

\section{Tabel 3}

Perbandingan aktivitas siswa dalam penggunaan model pembelajaran kooperatif tipe Make A Match siklus I dan siklus II

\begin{tabular}{|c|c|c|c|c|}
\hline Siklus Pertemuan & \multicolumn{2}{|c|}{ Siklus I } & \multicolumn{2}{c|}{ Siklus II } \\
\cline { 2 - 5 } ke- & P1 & P2 & P3 & P4 \\
\hline Jumlah skor & 16 & 19 & 20 & 22 \\
Skor maksimum & 24 & 24 & 24 & 24 \\
Persentase & $66,66 \%$ & $79,16 \%$ & $83,33 \%$ & $91,66 \%$ \\
Kategori & Cukup & Cukup & Baik & Baik \\
\hline
\end{tabular}

Berdasarkan tabel 3 dapat dijelaskan bahwa pada pertemuan pertama siklus I diperoleh aktivitas guru dengan skor 16 dengan persentase 66,66\% dengan kategori cukup. Sedangkan pada pertemuan kedua aktivitas siswa mengalami peningkatan dengan persentae $79,16 \%$ dengan total skor yang didapat 19 dengan kategori cukup. Pada siklus I pertemuan 1 dan 2 ini skor aktivitas siswa masih dikatakan cukup hal dikarenakan siswa belum sepenuhnya benar-benar mengikuti 
langkah-langkah pembelajaran dengan model pembelajaran kooperatif tipe Make A Match pada proses pembelajaran di kelas. Mereka masih terlihat meribut dan bermain pada saat pembelajaran berlangsung. Namun, pada pertemuan keduasiswa sudah terlihat bias mengikuti setiap tahapan, mereka sedikit lebih santai ketika melakukan kegiatan mengisi LKS dan juga memasangkan kartu. Dalam mengerjakan evaluasi mereka sedikit agak serius.

Observasi dilanjutkan dengan siklus II, pada pertemuan 3 siklus II skor aktivitas siswa sudah mengalami peningkatan dengan memperoleh skor 20 dengan persentase sebesar $83,33 \%$ dengan ketegori baik. Berbeda dengan pertemuan ke 4 pada siklus II, aktivitas siswa terus mengalami peningkatan hingga mencapai skor tertinggi yaitu 22 dengan $91,66 \%$ dengan kategori sangat baik.

\section{Hasil Belajar}

Ketuntasan pembelajaran IPS siswa dari ulangan harian siklus I, dan ulangan harian siklus II, mengalami peningkatan. Untuk melihatketuntasan pembelajaran IPS siswa berdasarkan skor dasar, ulangan harian siklus I, ulangan harian siklus II pada materi pokok sejarah uang, uang sebagai alat tukar dan kegunaan uang setelah diterapkan model pembelajaran kooperatif tipe Make $A$ Match di kelas III SD Muhammadiyah 6 2016/2017, selengkapnya dapat dilihat pada tabel dibawah ini :

Tabel 4

Peningkatan Hasil Belajar

\begin{tabular}{|c|c|c|c|c|c|c|c|c|}
\hline \multirow{2}{*}{ No } & \multirow{2}{*}{ Tahapan } & \multirow{2}{*}{$\begin{array}{c}\text { Jumlah } \\
\text { Siswa }\end{array}$} & \multicolumn{5}{|c|}{ Peningkatan Hasil Belajaran IPS } & \multirow{2}{*}{$\begin{array}{l}\text { Rata- } \\
\text { rata }\end{array}$} \\
\hline & & & SB & $\mathbf{B}$ & $\mathbf{C}$ & $\mathbf{K}$ & SK & \\
\hline 1 & Skor & & $1(5 \%)$ & $0(0 \%)$ & $7(35 \%)$ & $5(25 \%)$ & $7(35 \%)$ & 40 \\
\hline 2 & Siklus I & 20 & $3(15 \%)$ & $4(20 \%)$ & $9(45 \%)$ & $4(20 \%)$ & $0(0 \%)$ & 60 \\
\hline 3 & Siklus II & & $5(25 \%)$ & $5(25 \%)$ & $10(50 \%)$ & $0(0 \%)$ & $0(0 \%)$ & 90 \\
\hline
\end{tabular}

Berdasarkan tabel 4 dapat dilihat bahwa penilaian ketuntasan peningkatan hasil belajar IPS dari data awal yang diperoleh sebanyak 7 orang siswa termasuk dalam kategori sangat kurang dengan persentase $35 \%$, yaitu sis 3 , sis 6 , sis 11 , sis 12 , sis 13 , sis 16 , sis 19 . Siswa yang termasuk dalam kategori kurang 5 orang dengan persentase $25 \%$, yaitu sis 5 , sis 9 , sis 10 , sis 17 , dan sis 18 . Kemudian 
siswa yang termasuk dalam kategori cukup 7 orang dengan persentase $35 \%$, yaitu sis 1 , sis 2 , sis 4 , sis 8 , sis 14 , sis 15 , sis 20 dan dalam ketegori baik tidak ada seorangpun.Akan tetapi hanya satu siswa yang kategori sangat baik yaitu sis 7 dengan persentase $5 \%$.Dapat dilihat data awal dari hasil tabel diatas rata-rata yang diperoleh, dilihat dari standar Analisis hasil belajar tabel 3, termasuk kategori sangat kurang dengan rata-rata $40 \%$.

Pada siklus I ini siswa sudah mengalami peningkatan kemampuan hasil belajar, terlihat pada tabel diatas 3 orang yang sudah mencapai kategori sangat baik dari skor dasar sebesar $15 \%$ dari 3 siswa yaitu sis 2, sis 7, sis 8 . Kemudian siswa yang termasuk kategori baik sebanyak 4 orang dengan persentase $20 \%$, yaitu sis 1 , sis 4 , sis 5 , dan sis 14.Kategori cukup terdapat 9 orang dengan persentase $45 \%$ yaitu, sis 3 , sis 10 , sis 11 , sis 12 , sis 15 , sis 16 , sis 17 , sis 18 , sis 20. Dari skor diatas terdapat 1 orang siswa termasuk kurang dengan persentase $5 \%$ dan dalam kategorisangat kurang tidak seorang siswapun. Pada siklus I ini jelas jumlah siswa yang sangat baik mengalami peningkatan yang signifikan dikarenakan siswa berhasil mengikuti langkah-langkah pembelajaran dengan menggunakan model pembelajaran kooperatif tipe Make A Match serta siswa berhasil memaksimalkan kemampuan mereka dalam siklus lini. Siklus I pada pertemuan ini sudah cukup, karena dilihat dari rata-ratanya sebanyak $60 \%$ yang merujuk ke standar Analisis hasil belajar pada tabel 3.

Dilihat dari tabel 4, bahwa tidak ada lagi seorangpun yang termasuk kategori sangat kurang, akan tetapi masih banyak siswa yang termasuk pada kategori cukup dengan persentase $50 \%$ dari 10 siswa yaitu sis 3 , sis 9 , sis 10 , sis 12 , sis 13 , sis 15 , sis 16 , sis 17 , sis 18 , sis 19 , sis 20 .jelas banyak pertemuan dengan siswa-siswa mereka semakin terbiasa dengan kegiatan yang diberikan oleh guru melalui langkah-langkah kooperatif tipe Make A Match. Pada siklus II ini siswa yang baik juga telah membuktikan bahwa mereka telah mengerti, dan membuktikan mereka bisa memahami pembelajaran IPS. Peningkatan yang klasikal terlihat pada persentase yang termasuk kategori baik dilihat dari jumlah siswa 20 orang termasuk kategori baik sebanyak dari 5 orang persentase $25 \%$, yaitu sis 5 , sis 6 , sis 11 , sis 14 , dan sis 20 . Kemudian kategori sangat baik dilihat dari tabelyang sama jumlah siswa sebanyak 5 orang dengan rata-rata $25 \%$, yaitu sis 1 , sis 2 , sis 4 , sis 7 , sis 8 . Jelas terlihat perbandingan antara siklus II dan siklus 
I, dimana pada siklus I siswa masih ada yang tergolong kurang.Rata-rata tidak lepas dari pengukuran ke standar Analisis hasil belajar pada tabel 4, yang diperoleh $90 \%$ yang termasuk kategori sangat baik.

\section{PEMBAHASAN HASIL PENELITIAN}

Setelah proses pembelajaran dengan menggunakan model pembelajaran kooperatif tipe Make A Match terlihat hasil belajar IPS siswa meningkat. Data peningkatan hasil belajar IPS siswa dengan penerapan model pembelajaran kooperatif tipe Make A Match pada siswa kelas III SD Muhammadiyah 6 Pekanbaru dapat dilihat dari nilai rata-rata kelas siswa. Nilai rata-rata kelas siswa dapat dilihat pada tabel 5 :

Tabel 5

Rata-rata Peningkatan Hasil Belajar IPS Siswa dari skor dasar, siklus I,dan siklus II

\begin{tabular}{|c|c|c|}
\hline \multicolumn{2}{|c|}{ Rata-rata Meningkatkan Hasil Belajar IPS Siswa } \\
\hline Skor Dasar & Siklus I & Siklus II \\
\hline $40 \%$ & $65 \%$ & $90 \%$ \\
\hline
\end{tabular}

Berdasarkan tabel 5 datap dilihat peningkatan hasil belajar IPS siswa pada skor dasar yang diambil dari nilai rata-rata ulangan harian IPSsiswa sebelum diterapakan model pembelajaran kooperatif tipe Make A Match adalah 40\% (sangat kurang). Pada siklus I pada ulangan harian I nilai rata-rata siswa adalah 65\% (cukup).Pertemuan dilanjutkan pada siklus II.Pada siklus II dapat dilihat nilai rata-rata meningkatkan hasil belajar IPS siswa pada ulangan harian II terjadi peningkatan dengan nilai rata-rata yaitu $90 \%$ (sangat baik). Dengan demikian, hasil analisis tindakan ini mendukung hipotesis yang diajukan yaitu diterapkan model pembelajaran kooperatif tipe Make $A$ Match maka dapat meningkatkan hasil belajar IPS siswa kelas IIISD Muhammadiyah 6 Pekanbaru.

\section{SIMPULAN DAN SARAN}

\section{Simpulan}

Berdasarkan kajian dan analisis data yang telah disajikan pada BAB IV, maka dapat disimpulkan bahwa penerapan model pembelajaran kooperatif tipe Make A Match dapat meningkatkan hasil belajar IPS siswa kelas III SD 
Muhammadiyahi 6 Pekanbaru. Hal ini dapat dilihat dari hasil penelitian sebagai yaitut:

1. Peningkatan aktivitas siswa dalam pembelajaran IPS secara klasikal, dibuktikan dari jumlah siswa yang ke standar peningkatan hasil belajar IPS pada skor dasar rata-rata yang diperoleh sebesar 40\% dengan kategori sangat kurang. Pada siklus I rata-rata kemampuan apresiasi siswa sebesar $65 \%$ kategori cukup. Kemudian pada siklus II rata-rata diperoleh sebesar $90 \%$.

2. Penerapan model pembelajaran kooperatif tipe Make $A$ Match dalam proses pembelajaran mengalami peningkatan, hal ini dapat dilihat pada data aktivitas gurudan siswa. Rata-rata persentase aktivitas guru selama melaksanakan kegiatan pembelajaran meningkat dari 79,16\% (kategori cukup) pada siklus I, menjadi 95,83\% (kategori sangat baik) pada siklus II.

Rata-rata persentase aktivitas belajar siswa dalam kegiatan pembelajaran yang dilaksanakan mengalami peningkatan dari $66,66 \%$ (kategori cukup) pada siklus I, dan menjadi $83,33 \%$ (kategori baik) pada siklus II.

\section{Saran}

Berdasarkan hasil penelitian yang telah dilakukan, penelitian memberikan saran-saran yang berhubungan dengan penerapan model pembelajaran kooperatif tipe Make A Match yaitu:

1. Penerapan model pembelajaran kooperatif tipe Make A Match hendaknya dapat dijadikan salah satu strategi untuk memperbaiki proses pembelajaran IPS dikelas, diharapkan dapat menguasai langkah-langkah model pembelajaran kooperatif tipe Make $A$ Match sebelum melaksanakannya dalam proses pembelajaran, dan guru juga dapat mengelola kelas dengan baik serta melakukan refleksi setelah terlaksananya proses pembelajaran tersebut, karena dapat dijadikan acuan lembar observasi guru dari pertemuan pertama sampai keenam terlihat terjadi peningkatan yang tadinya guru tidak terbiasa dengan langkah-langkah pembelajaran kooperatif tipe Make A Match, dan pada pertemuan keenam guru hanya melanjutkan dan terbiasa dengan langkah-langkah pembelajaran kooperatif tipe Make A Match.

2. Penerapan model pembelajaran kooperatif tipe Make $A$ Match meningkatkan proses pembelajaran. Ini dapat dilihat dari meningkatnya aktivitas guru dan siswa. Oleh sebab itu, guru harus menguasai kelas dengan baik pada saat 
menggunakan model pembelajaran kooperatif tipe Make $A$ Match dan agar lebih efisien menggunakan waktu.

\section{DAFTAR PUSTAKA}

Depdiknas. 2006. Kurikulum Tingkat Satuan Pendidikan. Jakarta: Pusat Kurikulum Depdiknas.

Israni. 2011. 58 Model Pembelajaran Inovasi Referensi Guru Dalam Menentukan Model Pembelajaran,Medan : Media Persada.

Basyiruddin Usman, 2002. Metodologi Pembelajaran Agama Islam.Jakarta : Ciputar Pers.

Udin S. Winatapura, dkk.2008. Materi dan Penerapan IPS S. Jakarta: Universitas Terbuka.

Mihtahul Huda. 2013. Model-model Pengajaran dan Pembelajaran. Yogyakarta: Pustaka Pelajar.

Rusman. 2011. Model-model Pembelajaran Mengembangkan Profesionalisme Guru. Jakarta: Rajawali Pers.

Nana Sujana.1992. Penilaian Hasil Proses Belajar Mengajar PT. Remaja Rosda Karya Bandung.

Zainal Aqib. 2006. Penelitian Tindakan Kelas.Bandung CV Yuama Widia. 